\title{
Climate Ambition and Sustainable Development for a New Decade: A Catalytic Framework
}

\author{
Sander Chan
}

German Development Institute/Deutsches Institut für Entwicklungspolitik (DIE), and

Global Center on Adaptation (GCA), and

Utrecht University

Idil Boran (1)

German Development Institute/Deutsches Institut für Entwicklungspolitik (DIE), and

York University

Harro vanAsselt

Utrecht University, and University of Eastern Finland

Paula Ellinger

Fundación avina

Miriam Garcia

University of São Paulo

Thomas Hale

University of Oxford

Lukas Hermwille

Wuppertal Institute for Climate, Environment and Energy, and VU University Amsterdam

Kennedy Liti Mbeva (1) University of Melbourne, and African Research \& Impact Network (ARIN) Ayşem Mert Stockholm University Charles B. Roger Institut Barcelona d'Estudis Internacionals (IBEI) Amy Weinfurter WaterNow Alliance 
Oscar Widerberg

VU University Amsterdam

Paulette Bynoe

University of Guyana

Victoria Chengo

African Research \& Impact Network (ARIN)

Ayman Cherkaoui

Centre for International Sustainable Development Law

Todd Edwards

Mission 2020

Malin Gütschow

Leipzig University; Helmholtz Center for Environmental Research (UFZ)

Angel Hsu

University of North Carolina, and Yale-NUS College Nathan Hultman

University of Maryland

David Levaï IDDRI, and UN Foundation

Saffran Mihnar

EarthLanka Sara Posa

World Benchmarking Alliance

Mark Roelfsema

Utrecht University

Bryce Rudyk

New York University

Michelle Scobie

University of the West Indies

Manish Kumar Shrivastava

TERI School of Advanced Studies 


\section{Abstract}

This paper examines the Global Climate Action Agenda (GCAA) and discusses options to improve sub- and non-state involvement in post-2020 climate governance. A framework that stimulates sub- and non-state action is a necessary complement to national governmental action, as the latter falls short of achieving low-carbon and climate-resilient development as envisaged in the Paris Agreement. Applying design principles for an ideal-type orchestration framework, we review literature and gather expert judgements to assess whether the GCAA has been collaborative, comprehensive, evaluative and catalytic. Results show that there has been greater coordination among orchestrators, for instance in the organization of events. However, mobilization efforts remain event-driven and too little effort is invested in understanding the progress of sub- and non-state action. Data collection has improved, although more sophisticated indicators are needed to evaluate climate and sustainable development impacts. Finally, the GCAA has recorded more action, but relatively little by actors in developing countries. As the world seeks to recover from the COVID-19 crisis and enters a new decade of climate action, the GCAA could make a vital contribution in challenging times by helping governments keep and enhance climate commitments; strengthening capacity for suband non-state action; enabling accountability; and realizing sustainable development.

\section{Policy Implications}

- A post-2020 action space within the UNFCCC process remains crucial and might even be more important than before.

- A post-2020 Global Climate Action Agenda could exemplify a new avenue of cooperation, featuring effective international cooperation not only between governments, but also with, and between, sub- and non-state actors that provide solutions in a highly interconnected and globalized world.

- The transition from the pre-2020 climate action agenda to a post-2020 agenda provides a political opportunity to recalibrate the design of a catalytic framework that effectively responds to the need for successful international cooperation and effective implementation of the Paris Agreement.

- A post-2020 agenda should help accelerate implementation at the national level, amplify ambition of subsequent NDC cycles, and inform ambitious 'long term strategies'.

- Through collaboration with regional and national processes action, the Global Climate Action Agenda could more effectively encourage the engagement of sub- and non-state climate action at lower levels of governance.

- Collaboration between multiple platforms that orchestrate climate and sustainable development action could improve reflexivity and deliberativeness of governance practices. Such could also help generate outcomes that are considered more just when trade-offs occur between different aspects of sustainable development.

- By seizing opportunities and expanding the post-2020 Global Climate Action Agenda according to the design principles of a collaborative, comprehensive, evaluative and catalytic framework, it would not only improve upon previous engagement activities in the context of the UNFCCC, but also make a vital contribution to climate action in challenging times.

\section{Linking intergovernmental climate governance and sub- and non-state action}

The 2015 Paris Agreement marked a major shift in the climate regime ${ }^{1}$. Instead of allocating greenhouse gas (GHG) emissions targets between governments, it introduced a process whereby countries define their own climate targets, called 'nationally determined contributions' (NDCs), which would be reviewed and strengthened periodically. Moreover, the decision adopting the Paris Agreement recognizes the role of sub- and non-state actors, including cities, regions, businesses, investors, civil society organizations and the transnational initiatives and networks in which they are engaged. It calls upon such 'non-party stakeholders' to pledge and help deliver climate action (Andonova et al., 2017; Chan et al., 2016; Hale, 2016; Roger et al., 2017). They are no longer considered 'mere' observers to, and subjects of, the intergovernmental process, but vital contributors to the implementation of climate targets. In this context, the United Nations Framework Convention on Climate Change (UNFCCC) is not only facilitating intergovernmental negotiations, but increasingly building links between these negotiations and sub- and non-state actors (Hale, 2016).
While deeper intergovernmental climate cooperation remains elusive after the Paris Agreement, the shift towards polycentric climate governance could set the stage for increasingly ambitious climate action (Hale, 2020; Jordan et al., 2015; Keohane and Victor, 2016). Sub- and non-state actions do not substitute governmental efforts but through repeated interactions they can build trust and incrementally incentivize more ambition and international cooperation. As current governmental policies fall far short from the low-carbon and climate resilient development pathway envisaged in the Paris Agreement, sub- and non-state action appears to be critical for realizing low-carbon and climate-resilient development, and for addressing persistent mitigation, financing and other ambition gaps in climate governance (Hsu et al., 2020; Kuramochi et al., 2020; Lui et al., 2020). However, questions have been raised about the growing engagement of non- and sub-state actions in the climate regime. For instance, whether such efforts are effective in achieving their goals (Chan et al., 2019; Michaelowa and Michaelowa, 2017) and whether they contribute to growing complexity and fragmentation in governance, possibly raising legitimacy questions (Kuyper et al., 2018). Therefore, the question of whether institutional linkages between the 
state-centered climate regime and non-state and sub-state action can effectively catalyze climate action is critical (Hermwille, 2018).

In the lead-up to the Paris Agreement, a series of initiatives were undertaken to link the UNFCCC with non-party stakeholders. These included efforts by successive presidencies of the UNFCCC's Conference of the Parties (COP) and the UNFCCC Secretariat to catalyze action, in particular the 'Lima-Paris Action Agenda' (LPAA), which launched 70 largescale cooperative initiatives ahead of COP21 in Paris; a Technical Examination Process, which brings together sub- and non-state actors as well as parties to jointly consider climate change mitigation solutions (TEP-M); the 'Non-state Actor Zone for Climate Action' (NAZCA) now known as the 'Global Climate Action Portal' (GCAP), which records sub- and nonstate action; Action for Climate Empowerment (ACE), which develops educational and awareness programs, and promotes public participation; and the Momentum for Change initiative, which highlights promising replicable and scalable projects. Moreover, since COP21, the UNFCCC has launched a Technical Examination Process on Adaptation (TEP-A), and established the 'Marrakech Partnership for Global Climate Action' (MPGCA), which engages sub- and non-state actors through events at UN climate conferences, and reports on the progress of sub- and non-state actions in the Yearbook of Global Climate Action.

Outside of the formal UNFCCC process, similar engagement activities have been held, for instance the 2014 and 2019 UN Climate Summits, hosted by the United Nations Secretary General; the 2018 Global Climate Action Summit, convened by former California Governor Jerry Brown; and the recurring One Planet Summit, under the leadership of French President Emmanuel Macron. In addition, thematic events and 'Regional Climate Weeks' have been held in Africa, Latin-America and the Caribbean, and the Asia-Pacific region. While these moments and activities are driven by different actors, they seek to build on each other's efforts by collaborating and recognizing each other's initiatives. We gather these functionally and programmatically linked activities under the single heading of 'Global Climate Action Agenda' (GCAA) (see Figure 1), as they comprise the major sub- and non-state engagement processes in global climate governance. Our understanding of GCAA as functionally and programmatically linked activities to mobilize and engage non-state and subnational actors in climate action is not intended to be comprehensive; for instance, our analysis does not include many processes at the regional and national levels. Instead, we focus on GCAA processes that are more proximate to the UNFCCC process.

Despite growing interest in the GCAA (e.g. Chan et al., 2018a; Widerberg, 2017), a comprehensive evaluation is missing. Such an evaluation is timely for several reasons. First, the GCAA encompasses several activities known as the 'pre-2020 Agenda', a UNFCCC workstream dedicated to immediate action, which was opened in 2011 alongside the negotiations track towards the Paris Agreement. This workstream began exploring the potential for 'non-party' initiatives to reduce emissions before the adoption of a new agreement. Following a decision at the COP25 in Madrid in 2019, many activities are set to continue beyond 2020, including the MPGCA, the appointment of 'High-Level Climate Action Champions' (UNFCCC, 2019a) and the tracking of voluntary action in the NAZCA portal (UNFCCC, 2019a). While such an extension of UNFCCC activities is vital to the functioning and coordination within the GCAA, important opportunities arise to significantly improve links between sub- and non-state actors, governments and the intergovernmental process as we enter a new decade of climate action. Second, the UNFCCC has mostly completed its institutional architecture with the adoption of the Paris Agreement and the corresponding 'rulebook' at COP24 in Katowice. The emphasis of future COPs will shift to implementation instead, and a well-designed GCAA could be a vital part of this shift in focus. Moreover, the global health and economic crisis triggered by the COVID-19 pandemic has unexpectedly impacted the post-2020 outlook for climate action, creating an opportunity to reflect on, and improve, the GCAA. This crisis illustrates how delayed responses can prove costly, something that also holds true for the climate crisis. While governments decide on sustainable recovery packages, sub- and non-state actors should promote sustainable practices, including reducing greenhouse gases and building resilience to climate impacts. However, such efforts cannot be assumed, as both state and non-state actors may prioritize immediate economic recovery over long-term decarbonization and climate-resilient development. A post-2020 GCAA should help state and nonstate actors to simultaneously pursue economic recovery and sustainable development.

\section{Our approach and analytical framework}

This study builds on an inclusive multidisciplinary dialogue involving researchers, practitioners, and decision-makers from both developed and developing countries. It aims to review the GCAA and to discuss options for improving suband non-state actor engagement in the post-2020 climate regime. In the following, we explain our approach.

First, we introduce a heuristic framework based on institutional design principles. Then, we assess the extent to which these principles have been met by reviewing scholarly literature as well as 'grey literature', for instance reports and studies by experts and international organizations. An exceptionally diverse and multidisciplinary group of co-authors helped to ensure the inclusion of relevant literature since 2015. Finally, based on the literature review and our multidisciplinary dialogue, the GCAA is evaluated and opportunities are highlighted to strengthen the action agenda in the post-2020 context.

We derive our heuristic framework from Chan et al. (2015), who propose design principles for a sub- and nonstate engagement framework, based on earlier experiences of UN organizations involved in mobilizing sub- and nonstate actors in sustainability governance, and building on the 'orchestration' literature (Abbott and Snidal, 2010; Abbott et al., 2016; Hale and Roger, 2014). Proponents of 
Figure 1. GCAA as set of activities linking action by sub- and non-state actors to international and UNFCCC processes.

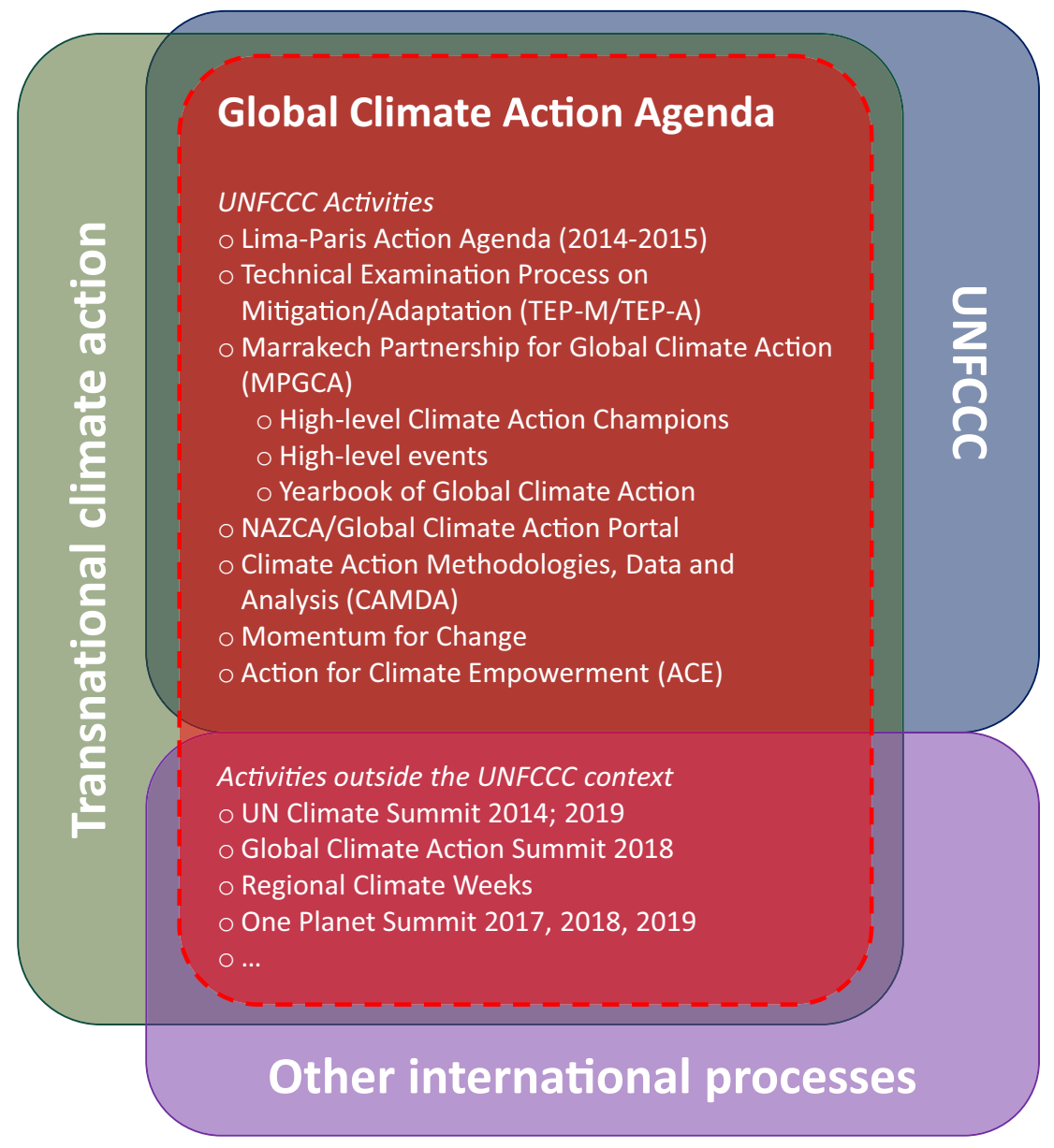

orchestration view international organizations as facilitators of engagement to achieve public goals through the actions of intermediary actors. Critically, the orchestrator does not or cannot - order target actors to pursue certain objectives, but rather enlists intermediaries, for instance partnerships and collaborative networks, who in turn reach out to target actors. In so doing, the orchestrator steers at arm's length to ensure that intermediaries' actions promote its policy agenda (Abbott et al., 2016). Fragmented issue areas such as climate change are most suitable for such steering. Research on orchestration has focused, in particular, on explaining the occurrence of orchestration (Abbott 2015), the motives behind orchestration efforts, as well as their effectiveness in reaching these goals (Abbott and Snidal, 2010; Chan et al., 2015; Chan and Pauw, 2014; Hale and Roger, 2014). As orchestration contributes to structuring in a fragmented climate governance context without applying hierarchical forms of direct control and authority, it is a central concept for evaluating GCAA (Abbott, 2015).

To strengthen sub- and non-state engagement in the realization of global climate goals, Chan et al. (2015) proposed that orchestration in the UNFCCC context should be collaborative, comprehensive, evaluative, and catalytic. While we recognize that overlaps exist between these design principles (e.g. the recording of climate action involves collaboration, and is also fundamental for the evaluation of non-state efforts), they are useful as a heuristic tool to evaluate the GCAA. In the following, we describe each design principle, as well as explain how we assess activities in the GCAA to determine the extent to which a principle has materialized since 2015.

First, the framework should be collaborative by sharing design and operational responsibilities between key orchestrators, including the UNFCCC Secretariat, COP presidencies, other international organizations, sub- and non-state actors, and governmental partners in cooperative initiatives. Functions such as the recording, monitoring and support of climate actions, maintaining registration platforms, and the organization of events, are already performed individually. In a collaborative framework different actors fulfill functions more efficiently than a single orchestrator might (Biermann et al., 2012). We assess the extent to which the GCAA is collaborative by observing coordination between orchestrators over time across levels of governance, and between major mobilization processes - particularly between climate action summits since 2015 - as well as collaboration in the recording of mobilized actions. 
Second, the framework should be comprehensive in that it provides a systematic overview of functional and participatory patterns of mitigation, adaptation and other climate actions across the broad landscape of sub- and non-state engagement. Such an overview helps to highlight in which areas more engagement may be needed and what types of actions are warranted, thereby informing strategic interventions and policy priorities for orchestrators. We assess comprehensiveness by observing the growth in recorded actions both vis-à-vis mitigation and adaptation, and whether and to which extent actions involve underrepresented sectors and actors.

Third, the framework should be evaluative by creating common methods and benchmarks for assessing progress. Systematic tracking of impacts could help governments assess the contribution of sub- and non-state actors. Best performers could also be identified, incentivizing them and others to accelerate implementation and heighten ambition. To assess this, we observe the progress made on methodologies to evaluate sub- and non-state actions, both in terms of (ex ante) commitment-making and in terms of (ex post) changes in environmental and social impacts.

Finally, an orchestration framework should be catalytic (Hale, 2020), generating additional climate action, particularly in thematic and geographic areas where more action is needed. To assess this, we focus on the demand for nonstate and climate action in developing countries and whether a higher growth of (recorded) climate action can be observed.

\section{A collaborative GCAA?}

First steps towards a collaborative GCAA were taken prior to the 2015 Paris Climate Conference. The LPAA was set up by Peru and France (respectively the presidencies of COP20 and COP21) to mobilize sub- and non-state climate action, in close collaboration with the UNFCCC Secretariat, and the Office of the UN Secretary-General, which had previously organized the 2014 UN Climate Summit. The Peruvian government also launched the NAZCA portal, with support from the UNFCCC Secretariat. Under the pre-2020 agenda, the UNFCCC Secretariat organized sectoral conversations under the TEP to demonstrate the potential of mitigation solutions, involving joint programming with multiple organizations beyond the UNFCCC.

The capacity for longer-term coordination and collaboration on climate action received a strong boost in the COP21 decision accompanying the Paris Agreement. Besides adding a TEP on adaptation, it called on the UNFCCC Secretariat to annually summarize meetings under the TEPs for policymakers (UNFCCC, 2015); encouraged sub- and non-state actors to register their commitments through the NAZCA portal; and established the position of High-level Climate Action Champions, tasking them with the organization of annual high-level events to convene state and non-state dignitaries at every COP until 2020 (Chan et al., 2016; Hsu et al., 2018). The newly appointed Champions launched the MPGCA in 2016 to liaise with stakeholders across various thematic and cross-cutting areas (land use; oceans and coastal zones; water; human settlements; transport; energy; industry; climate resilience and climate finance); to facilitate dialogue between government and sub- and non-state actors; and to organize high-level events. Moreover, in recent years, the GCAA has increasingly sought to coordinate activities regionally, with Champions integrating 'Regional Climate Weeks' in the Asia-Pacific region, Africa and Latin America into their work plans.

While the MPGCA and the Champions raised the institutional capacity to coordinate among multiple actors, collaboration in terms of brokering new coalitions and launching new initiatives remains largely event-driven. Since 2015, major summits, such as the 2017 One Planet Summit, the 2018 Climate Action Summit and the 2019 UN Climate Summit, have been designed and organized outside of the UNFCCC. These events have been criticized for the enormous effort they require, and the ensuing fatigue among sub- and non-state actors to yet again generate new announcements, possibly distracting from other vital functions. For instance, while many commitments are announced at these summits, once out of the public eye, little effort is invested in understanding their progress (Dinesh, 2019). The GCAA, however, plays an important role by recording commitments and bringing them into its collaborative data-collection and management environment, even when a platform such as NAZCA could still be better structured to allow for more easy data extraction and processing to facilitate analyses (see GO FAIR n.d.).

\section{A comprehensive GCAA?}

Chan et al. (2015) argued that an orchestration framework should be comprehensive by bringing together information from existing sources and registries of sub- and non-state actions. In terms of recording many sub- and non-state actions across a wide range of sectors, the GCAA could be considered successful. The longest continuous collaborative effort within the GCAA has been the UNFCCC-administered NAZCA portal. Since its launch in 2014, the portal has recorded a growing number of sub- and non-state climate actions and 'cooperative initiatives'. In contrast to earlier UN registration platforms, data are provided by various external data partners (CDP, Carbon Climate Registry, The Climate Group, Global Investor Coalition on Climate Change, UN Global Compact, Global Covenant of Mayors, Climate Bonds Initiative and UN Environment's Climate Initiatives Platform). This innovative collaboration moved much of the labor- and capital-intensive data-gathering outside of the UNFCCC. Furthermore, it depoliticized decisions on the inclusion and exclusion of particular initiatives. The close cooperation between the GCAA and data providers resulted in more recorded actions, from just over 900 commitments in 2014 to over 27,000 in 2020. However, comprehensiveness of data should be evaluated by more sophisticated indicators than large numbers.

First, it remains unclear if an increasing number of recorded actions are conducive to the decarbonization of 
the global economy and to more sustainable and climate-resilient pathways. The NAZCA portal does not assess the consistency of these actions with the goals of the Paris Agreement, their timeframes or the pathways to getting there. Large parts of the economy also remain absent from NAZCA (Hsu et al., 2016), including some of the most polluting sectors, including aviation or fossil-fuel industries, while businesses less affected by consumer scrutiny are also less likely to take action. Such gaps in current records of climate action hinder efforts to expand or correct activities, and to identify drivers of, and roadblocks to, low-carbon and climate resilient development. Second, comprehensiveness also depends on what counts as relevant action under the GCAA. The pre-2020 agenda highlighted the transnational contribution to climate mitigation rather than adaptation (Chan et al., 2016). Since then, adaptation actions have been emphasized at summits, and in the work of the Champions. And yet, adaptation actions are less recorded and remain underrepresented on platforms such as NAZCA, as well as at various climate summits (Chan and Amling, 2019). Moreover, despite a strong connection between climate action and other aspects of sustainable development, data collection does not systematically consider impacts on sustainable development. The lack of such data may be a missed opportunity for furthering action in the context of systemic transformation.

Going forward, more comprehensive data on sub- and non-state action in underrepresented sectors, and on economic, environmental and social impacts, would help the GCAA and other mobilization processes to address participatory imbalances in climate action, lagging sectors or underserved communities.

\section{An evaluative GCAA?}

While collaboration among data providers was already well established by 2015 , collaboration on the evaluation of suband non-state action was much less developed. Instead of evaluation, efforts ahead of the Paris Climate Conference prioritized the demonstration of the growing scale of sub- and non-state efforts and their support for governments to negotiate an ambitious deal (Jacobs, 2016). The LPAA acted on an 'intervention theory' that such a growing scale of action would encourage states to sign up to the global agreement (Widerberg, 2017). Arguably, many commitments were still too new to evaluate their impacts (Chan et al., 2018b), and assessments of whether actors kept their promises have long been hindered by a lack of analytical tools (Widerberg and Stripple, 2016). The earliest evaluations of the mitigation impact of transnational actors were not based on actual commitments, but on estimates of mitigation potential within key sectors (e.g. Blok et al., 2012).

Progress has been made on methodologies to evaluate the impact of sub- and non-state commitments (e.g. Hsu et al., 2018, 2019a, 2019b; Hultman et al., 2018, 2019, 2020). The number of evaluations has also been increasing, especially with regards to the potential to reduce GHG emissions. Subsequent publications have highlighted the mitigation potential of both individual and cooperative initiatives registered in the NAZCA database (Hsu et al., 2015; Kuramochi et al., 2020; Lui et al., 2020; NewClimate et al., ; Roelfsema et al., 2018; UNEP, 2019). Reporting on climate action remains time- and resource-intensive, which may deter suband non-state actors, particularly those with limited capacity. Lower-cost alternatives to traditional forms of data collection may eventually help build transparency without discouraging actors. For instance, the Global Covenant of Mayors and Google's pilot 'Environmental Insights Explorer' leverages global mapping data with GHG emission factors to estimate city-scale building and transportation emissions (Google n.d.). Technology-driven approaches such as combining the Internet of Things with blockchain technology could also eventually automate reporting in sectors like renewable energy (Hsu et al., 2020b).

Crucially, the UNFCCC Secretariat has fostered closer cooperation with the analytical and data communities by co-convening meetings under the 'Climate Action Methodologies Data and Analysis' ('Camda') group, which is a collaborative body with over 30 organizations aiming to ensure credible climate action by connecting and aligning reporting, data collection, and analytical methods. As a first step, the UNFCCC Secretariat, data providers and leading researchers developed a roadmap towards common methods and benchmarks to quantify mitigation actions (Hsu et al., 2019b). Such harmonization would help build more coherent and consistent data sets that are more readily available to analysts (Van Staden and Appleby, 2019).

While growing cooperation gives reason for optimism about the GCAA's capacity to become an evaluative framework, important gaps remain. First, the strong focus on mitigation impacts seems too narrow in the UNFCCC context, which demands more data on adaptation, climate resilience, and sustainable development (co-)benefits. Part of the difficulty of tracking and analyzing impacts beyond mitigation is due to the diversity of actions, many of which cannot easily be quantified and compared across large samples. Nonetheless, researchers have developed methods for tracking nonmitigation impacts, creating proxies in the absence of data on societal and environmental impacts (Chan et al., 2018b, 2019; Dzebo, 2019; Hale et al., 2020). The MPGCA has reported proximate indicators of impacts beyond mitigation for a limited set of cooperative initiatives in recent editions of the Yearbook of Global Climate Action (UNFCCC, 2017, 2018, 2019b). However, the NAZCA portal, the GCAA's main tracking tool, has yet to incorporate systematic tracking of targets and impacts beyond mitigation. Second, as governments implement and revise their NDCs, accurate data are needed at the country level to inform interactions with other actors. Initial investigations on the mitigation potential of sub- and non-state actors in 10 high-emitting economies present a promising step in the right direction (Kuramochi et al., 2020; Lui et al., 2020). However, they still assume full implementation of commitments, which is unlikely when many actions lack robust institutional designs (Michaelowa and Michaelowa 2017) or when political and economic priorities change with the current COVID-19 crisis. Moreover, 
assessments do not account for possibly substitutive relations between state and non-state actions.

Finally, the tracking of climate action falls short of evaluating actualized (ex post) environmental and social impacts. This also holds true for tracking GHG emission reductions that mostly relies on self-reported targets and commitments (Chan et al., 2019; Hsu et al., 2019b). The further development of GCAA as an evaluative framework will be crucial for the credibility of sub- and non-state action, as their growth alone is not meaningful if many remain commitments on paper. Moreover, an evaluative GCAA will be vital to provide specific data to help governments implement policies, track progress and increase climate ambition.

\section{A catalytic GCAA?}

Finally, according to Chan et al. (2015), an orchestration framework should be catalytic, generating additional, and more ambitious, climate action particularly where it is most needed. Evaluating the catalytic impact of the GCAA is difficult but it arguably should, at least, be evident in higher growth rates of new climate initiatives, particularly where such action is most needed, for instance in the global South.

The growing number of commitments recorded might lead to a positive evaluation of the GCAA. The NAZCA portal reveals a growing scale and scope of climate action; more than 10,000 cities and regions have made commitments, alongside more than 6,000 businesses, representing an annual revenue greater than the combined GDPs of China and the United States (UNFCCC, 2019b). However, it is difficult to ascertain how much of this growth is due to the GCAA. Nonetheless, much of the GCAA is premised on its ability to inspire and support commitment-making. The demonstration objective of TEMs and the Talanoa Dialogue, a UNFCCC process held in 2018 designed to help countries implement and enhance their NDCs by 2020, are clear examples of non-state solutions being presented to governments in the hope that these will inspire application of suband non-state solutions at scale. The UNFCCC's Momentum for Change Initiative awards 'lighthouse packages' (recently rebranded as 'UN Global Climate Action Awards'), highlighting particularly innovative, ambitious, scalable and replicable actions across thematic areas (e.g. gender, IT, and climatefriendly investment). UNFCCC efforts therefore presuppose the effectiveness of demonstration, and subsequent scaling and replication by other (particularly public) actors. Currently, however, evidence on the impact of the GCAA remains anecdotal. Processes to engage more actors prioritize the launching and showcasing of new commitments, rather than demonstrating progress towards keeping existing commitments.

In 2015, a particular concern was to catalyze climate action in developing countries to address their relative underrepresentation. While the past five years have seen increased representation from sub- and non-state actors in developing and emerging economies (Global Covenant of Mayors, 2018), these actors continue to be underrepresented in NAZCA and in other records (Andonova et al., 2017). The number of recorded cooperative climate initiatives rose 56 per cent in low-income countries, and 50 percent in lowermiddle income countries, between 2015 and 2017, but climate initiatives remain overwhelmingly based in the global North (Chan et al., 2018b; UNFCCC, 2017, 2018, 2019b). NonOECD countries still account for only 22 per cent of participation in cooperative initiatives, and 23 percent of the lead partners of initiatives (ClimateSouth, 2018). Many actions for instance by small and medium-sized enterprises - in developing countries remain under the radar. Efforts within the GCAA to engage large investors and multinational corporations, few based in developing countries, may also lead to biased representation. Additionally, some developing country-based actions elude international tracking efforts because they operate in languages other than English, or their actions may be framed in terms of sustainable development rather than climate action, despite contributing to climate goals. A survey in Kenya and India found that many actions by cities, counties, and businesses were not captured by international reports; for instance, NAZCA recorded just two companies making climate commitments in Kenya, but a closer examination of Nairobi Stock Exchange listed companies identified nearly 50 companies with concrete emissions reduction targets (ClimateSouth, 2018). Data-gathering arrangements in the GCAA may have also contributed to the reproduction of biases, as data partners are largely based in North America and Europe.

Finally, developing countries refer to sub- and non-state actors in their NDCs much more frequently than higher-income countries, particularly in relation to adaptation to climate change (Hsu et al., 2019a). An appropriate response by the GCAA may therefore not only be about improving the visibility and recognition of south-based action, but also about strengthening capacities for sub- and non-state actors to contribute to implementation in developing countries.

\section{Global climate action for a new decade: seizing new opportunities}

A post-2020 action space within the UNFCCC process remains crucial and might even be more important than before. First, the UNFCCC, which has predominantly focused on negotiations towards international agreements, has found itself in a post-Paris climate governance context which emphasizes implementation. Through the GCAA, the UNFCCC could continue to promote the contribution of transnational actors in climate governance and play a relevant role in accelerating implementation, for instance, by helping national governments and sub- and non-state actors engage with each other in the implementation of NDCs and in the development of more ambitious commitments. Second, and more broadly still, the COVID-19 crisis introduces a critical moment to reinvigorate international solidarity, multilateralism and cooperation to better address transboundary economic, public health, and environmental challenges. In this context, the GCAA could exemplify a new avenue of cooperation, featuring effective international cooperation 
not only between governments, but also with and between sub- and non-state actors that provide solutions in a highly interconnected and globalized world.

The transition from the pre-2020 climate action agenda to a post-2020 GCAA provides a political opportunity to recalibrate the design of the framework, and to effectively respond to the need for successful international cooperation and effective implementation. In this context, we highlight opportunities for sub- and non-state actors to drive national implementation and ambition; to enable sub- and non-state climate action at the regional and national levels; and to realize with broader sustainable development goals, while applying the principles of a comprehensive, collaborative, evaluative, and catalytic action agenda.

\section{Driving national implementation and ambition}

The year 2020 coincided with the beginning of the first implementation cycle of the Paris Agreement. A post-2020 agenda should help accelerate implementation at the national level, amplify ambition of subsequent NDC cycles, and inform ambitious 'long-term strategies' (LTS) for midcentury low-carbon development (Chan et al., 2019; Hermwille, 2018). Ambitious non-state actors could inspire governments and give them confidence to adopt more ambitious targets under the Paris Agreement. A post-2020 GCAA could facilitate 'NDC labs' which, for instance building on sectoral 'Climate Action Pathways' (UNFCCC, 2020), would provide input and feedback at the request of governments on how they could strengthen their capacity in specific areas of interest, and subsequently deliver on, and strengthen their NDCs (Galvanizing the Groundswell of Climate Actions, 2019). Moreover, the GCAA could stimulate the aggregation of impacts of climate action at the national level, rather than at the international level. This would help governments to better understand sub- and non-state contributions to implementation, and find opportunities for strengthening climate targets. For instance, America's Pledge, a coalition of sub- and non-state actors in the United States, has demonstrated the impact of non-party stakeholder action through a comprehensive national-level analysis, pointing out opportunities to adopt higher levels of ambition in the US (Hultman et al., 2018, 2019). While comprehensive national-level data may be difficult to acquire through NAZCA partners, general guidance can help governments, particularly in technical tasks such as the accounting of non-state contributions. Such guidance should take into account variation across NDCs and sub- and non-state arrangements at the national level (Hsu et al., 2019a). In this regard, an important development vis-à-vis mitigation is the guidance on non-state action developed by the Initiative for Climate Action Transparency (ICAT, 2018) to help governments integrate the impact of sub- and non-state mitigation actions into greenhouse gas projections, targets and planning. Such integration of sub- and non-state impacts, however, hinges on the availability of reliable methods and data, and requires collaboration between governments, sub- and non-state actors at the national level. Notably, context- dependent and nationally specific collaboration has been particularly prominent in Latin America, where around 14 countries have developed their NDCs in collaboration with non-state actors, and multi-sectoral dialogues have been set up in Argentina, Costa Rica and Peru (European Commission, 2019). Similarly, several international NGOs and global networks, including the World Wildlife Fund (WWF), The Climate Group, the C40 Cities Climate Leadership Group, and the We Mean Business coalition, have set up the 'Alliances for Climate Action' (ACA) initiative, which builds national coalitions of sub- and non-state actors to create supportive constituencies to champion and accelerate climate action; encourage collaboration; and foster learning at the national level (ACA, 2020).

The year 2023 is important for making progress on the evaluative functions of the GCAA (and every five years thereafter), as the first 'global stocktake' will be held under the Paris Agreement to assess 'collective progress', and to inform subsequent NDCs (Hermwille et al., 2019). In their assessments, governments should integrate data on climate actions into national target setting and implementation, including national GHG projections, and new and enhanced NDCs. Sub- and non-state actors should translate and interpret the results of the global stocktake to their respective national, regional, local contexts (Hermwille et al., 2019).

\section{Enabling sub- and non-state climate action nationally and regionally}

The GCAA, although placing political emphasis on the need for action in developing countries, has not featured a balanced geographic representation so far. Fortunately, recent years have seen the proliferation of efforts to stimulate suband non-state climate action, both at the regional and national levels, and in specific sectors (Chan et al., 2018a, 2019). For instance, Kenya, Uganda, Tanzania, and Rwanda launched the East African Climate Change Technical Working Group to foster cooperation and the engagement with non-state actors (Namande, 2018); Regional Climate Weeks have been organized in Africa, Latin America and the Caribbean, Asia Pacific, bringing together regional stakeholders from the public and private sectors to jointly address climate change; and the Green Climate Fund (GCF) seeks to strengthen institutional capacities through its Readiness Program, which provides funding for countries to develop stakeholder engagement processes and deploy climate finance more efficiently (GCF, 2020). Regional interactions also increasingly emerge from networks run by non-state actors, such as LEDSLAC (2020) and ActionLAC, which build bridges between representatives of national governments and non-state actors and build regional non-state capacity for climate action in Latin America. These processes play a complementary role to the GCAA in the global climate regime complex. Regional and national processes that foster climate action enable the participation of more stakeholders due to reduced language and logistical barriers, at the same time they provide a more targeted and contextualized framework for discussion (Chan et al., 2018a). Greater 
similarity between actors in comparable implementation contexts could also allow for a more experimental approach, where non-state commitments are treated as 'informal experiments' (Abbott, 2017; see also Bernstein and Hoffmann, 2018). Within such a framework, regional and national orchestrators could encourage different types of actions, and subsequently evaluate ongoing 'experiments' to distill and diffuse best practices.

Regional and national processes are likely to be more effective than an enlarged GCAA would be. They are more proximate to specific implementation contexts and policy demands; respond to topics that are particularly salient in these contexts; and are better positioned to encourage involvement from regional and national organizations in climate action.

The role of the GCAA in regional and national processes may be limited, but important. For instance, featuring Highlevel Climate Action Champions at regional and national events, demonstrates high-level support for regional and national orchestration processes and acknowledges their relevance to the Paris Agreement. However, the GCAA could also facilitate the sharing of experiences across the regional, national, and sectoral platforms. Beyond brokering new collaborations or showcasing action, such exchanges should aim at improving technical and operational aspects of mobilization, implementation, reporting, data management, and accountability procedures across regional and national platforms. They could also help connect both private and public finance with national and regional platforms, to co-design and optimize support mechanisms that enable local and regional climate action.

\section{Maximizing sustainable development synergies}

While early sub- and non-state engagement in the UNFCCC emphasized mitigation (Chan et al., 2016), climate action has become more comprehensive and the GCAA increasingly emphasizes adaptation. Long regarded as a primarily local issue, adaptation itself is increasingly seen through 'teleconnected' dependencies, for example, through pricing and global trade that link vulnerabilities across regions (Adger et al., 2009; Benzie and Persson, 2019). Climate action can even be more broadly framed, moving beyond mitigation and adaptation as discrete categories, and addressing multiple anthropogenic factors across social, ecological and economic systems that interact in non-linear ways, compounding risks and possibly leading to cascading effects (Bradley et al., 2020). For instance, biodiversity loss, climate change, and health risks are interrelated as threat multipliers. Climate change impacts exacerbate the decline of ecosystems, and human encroachment on ecosystems affects the spread of communicable diseases. Climate change impacts such as droughts disrupt agricultural productivity, leading to higher food prices, threatening food security and health especially among vulnerable communities (EASAC, 2019). The effects of climate change are compounded by heat islands in densely populated areas, negatively impacting public health in cities (Hobbhahn et al., 2019). The GCAA can encourage action with simultaneous impacts and co-benefits that enable broader sustainable development (Doswald and Osti, 2011; Scobie, 2019). The COVID-19 crisis illustrates the close connection between ecological, economic, and health systems, and highlights the need for a 'green recovery' that effectively abates an economic, ecological, health, and climate crisis altogether. Various approaches exist that can help maximize synergies and manage trade-offs between different sustainability aspects, for instance, 'planetary health' (Bradley et al., 2020; Watts et al., 2019), and 'ecosystem-based' or 'nature-based' approaches (Cohen-Shacham et al., 2016).

Institutionally, the GCAA could rise to the challenge through the thematic prioritization of specific sustainable development synergies. For instance, the COP25 decision emphasized climate action and the integrity of ocean and coastal ecosystems (UNFCCC, 2019a; paragraph 30). However, such priorities depend on changing COP presidencies, complicating a longer and sustained programmatic agenda. Another important opportunity arises from a generalized 'governance through goals' (Biermann et al., 2017) approach in sustainable development governance, particularly the 2030 Agenda and the SDGs. By setting international goals, governments have opened up a governance space for a multiplicity of actors and solutions to contribute towards goal achievement. Governance approaches across the UN system are converging towards engagement with sub- and non-state actors across multiple issue areas through orchestration. For instance, the Quito Implementation Platform for the New Urban Agenda (Marsal-Llacuna, 2018), the Agenda for People and Nature (Pattberg et al., 2019); and 'Partnerships for the SDGs' (Chan et al., 2019), all seek to engage sub- and non-state actors in the contexts of, respectively, UN Habitat, the Convention of Biodiversity (CBD), and the UN Department for Economic and Social Affairs (UN DESA). Together, these platforms allow for taking different entry points to link climate action to broader sustainable development. While these platforms operate separately, collaboration between the GCAA and other orchestrators in sustainable development governance holds great promise to demonstrate linkages between climate action and SDGs (UNFCCC, 2018, 2019b); and to develop operational synergies. Although such exchanges should aim to maximize synergies, they should also address trade-offs, creating indepth knowledge on both intended and unintended, beneficial and detrimental impacts of climate action, and circumstances that enable and amplify synergies. Such knowledge would be an important complement in the GCAA, where the production of quantifiable (climate mitigation) data has often been (over-)emphasized.

Collaboration between platforms that orchestrate climate and sustainable development action would also improve reflexivity and deliberativeness of governance practices and could be a major step towards promoting meaningful participation and democratic quality in decision-making (Dryzek and Pickering, 2018; Mert, 2019). While collaborating orchestration platforms may not avoid all possible trade-offs between different aspects of sustainable development, 
Table 1. Seizing opportunities for a post-2020 GCAA

\begin{tabular}{|c|c|c|c|c|}
\hline & Collaborative partners & Comprehensive information & Evaluative methods & Catalytic mechanisms \\
\hline $\begin{array}{l}\text { Strengthening } \\
\text { NDC } \\
\text { implementation } \\
\text { and ambition }\end{array}$ & $\begin{array}{l}\text { (NAZCA) data and } \\
\text { analytical partners }\end{array}$ & $\begin{array}{l}\text { National/NDC specific data; } \\
\text { data from developing } \\
\text { countries }\end{array}$ & $\begin{array}{l}\text { Assessments of national } \\
\text { level sub- and non-state } \\
\text { contributions at the } \\
\text { national level }\end{array}$ & $\begin{array}{l}\text { Recommendations and } \\
\text { effective national-level } \\
\text { engagement (e.g. ICAT, } \\
\text { NDC labs) }\end{array}$ \\
\hline $\begin{array}{l}\text { Strengthening } \\
\text { sub- and non- } \\
\text { state action } \\
\text { nationally and } \\
\text { regionally }\end{array}$ & $\begin{array}{l}\text { Regional and national } \\
\text { platforms; regional } \\
\text { climate weeks; } \\
\text { Alliances for Climate } \\
\text { Action }\end{array}$ & $\begin{array}{l}\text { Context-specific, scalable, good } \\
\text { practices }\end{array}$ & $\begin{array}{l}\text { Comparative analysis } \\
\text { between sub- and non- } \\
\text { state approaches; national- } \\
\text { level aggregation and } \\
\text { analysis of data }\end{array}$ & $\begin{array}{l}\text { Experience sharing between } \\
\text { platforms; support facilities } \\
\text { for sub- non-state actors } \\
\text { (e.g. readiness } \\
\text { programmes) }\end{array}$ \\
\hline $\begin{array}{l}\text { Realizing broader } \\
\text { sustainable } \\
\text { development }\end{array}$ & $\begin{array}{l}\text { UN orchestrators (e.g. } \\
\text { UN Habitat, CBD, UN } \\
\text { DESA) }\end{array}$ & $\begin{array}{l}\text { Information on synergic } \\
\text { opportunities and possible } \\
\text { conflicts; qualitative data on } \\
\text { systemic linkages and } \\
\text { cascading effects }\end{array}$ & $\begin{array}{l}\text { In-depth, qualitative, } \\
\text { analysis between different } \\
\text { aspects of sustainable } \\
\text { development }\end{array}$ & $\begin{array}{l}\text { Deliberative conflict } \\
\text { resolution; synergic } \\
\text { approaches; social } \\
\text { consensus building }\end{array}$ \\
\hline
\end{tabular}

deliberation may help build social consensus, generating outcomes that are considered more just (Bäckstrand and Kuyper, 2017; Bäckstrand et al., 2017).

\section{Discussion and recommendations}

Recent years have seen major steps taken towards linking state and non-state action. The pre-2020 agenda, the COP21 decision adopting the Paris Agreement, and the MPGCA further anchored sub- and non-state climate action in the UNFCCC's institutional ecosystem (Hale, 2016). If checked against Chan et al.'s (2015) design principles, important achievements have been made in the pre-2020 GCAA. The pre-2020 agenda highlighted the growing scale and scope of sub- and non-state action. The UNFCCC Secretariat has also consistently sought to advance its engagement efforts through collaborations. From its first attempts under the LPAA to recent climate action summits, the UNFCCC Secretariat ensured continuity in the promotion and recording of sub- and nonstate climate actions. It also engaged the analytical community to better assess such actions. While the extent to which the pre-2020 agenda was able to generate new and additional action is difficult to determine, by highlighting expanding engagement, the GCAA helped to drive relative optimism and the momentum for climate action, even when the climate regime was confronted with severe setbacks.

Our review has revealed several ways in which a post2020 GCAA can improve. Table 1 summarizes opportunities to strengthen NDC implementation and ambition; to support national and regional level climate action; to realize sustainable development synergies and to address possible conflicts. Following the design principles for the GCAA, such opportunities could be realized by expanding collaboration, achieving more comprehensive information, developing new evaluative methods and deploying catalytic mechanisms.
Importantly, seizing these opportunities will entail varying levels of governance and capacities. For instance, strengthening sub- and non-state action, expanding collaboration, data collection, and evaluation will mostly require efforts by national and regional actors. However, the GCAA could play a role in experience sharing, and facilitating relations with international financing and support facilities. Similarly, for deliberative processes between orchestration platforms, the GCAA will depend on strong inter-agency cooperation.

By seizing opportunities and expanding the GCAA into a new decade, according to the design principles of a collaborative, comprehensive, evaluative and catalytic framework, it would not only improve upon previous engagement activities in the context of the UNFCCC, but also make a vital contribution to climate action in challenging times. As the world seeks to recover from the COVID-19 crisis, a post-2020 GCAA can help governments keep and enhance their climate commitments, strengthen the sub- and non-state capacity for action, and help realize sustainable development.

\section{Note}

1. This article benefited from a transdisciplinary discussion that involved researchers and practitioners from both developed and developing countries and was organized by the 'Klimalog' research and dialogue project for a climate smart and just transformation at the German Development Institute/Deutsches Institut für Entwicklungspolitik (DIE), supported by the German Federal Ministry for Economic Cooperation and Development (BMZ). The discussion was held together with 'Galvanizing the Groundswell of Climate Actions' - a series of open dialogues that aims to bring the groundswell of climate actions from cities, regions, companies and other groups to a higher level of scale and ambition; York University (Canada); and the University of São Paulo.An international regime is defined as 'principles, norms, rules, and decision-making procedures around which actor expectations converge in a given issue-area' (Krasner 1982, p- 195). The 'climate regime' refers to the regime established by the 1992 United Nations Framework Convention on Climate Change (UNFCCC), which includes its subsequent rule development through the 1997 Kyoto Protocol 
and 2015 Paris Agreement, as well as decisions by the respective governing bodies of these treaties.

\section{References}

Abbott, K. W. (2012) 'The Transnational Regime Complex for Climate Change', Environment and Planning C: Government and Policy, 30 (4), pp. $571-590$.

Abbott, K. W. (2015) 'Orchestration', in A. J. Jordan (ed.), Governing Climate Change: polycentricity in action?. Cambridge: Cambridge University Press, pp. 188-209.

Abbott, K. W. (2017) 'Orchestrating Experimentation in Non-state Environmental Commitments', Environmental Politics, 26 (4), pp. 738 763.

Abbott, K. W., Genschel, P., Snidal, D. and Zangl, B. (2016) 'Two Logics of Indirect Governance: Delegation and Orchestration', British Journal of Political Science, 46 (4), pp. 719-729.

Abbott, K. W. and Snidal, D. (2010) 'International Regulation without International government: Improving 10 Performance through Orchestration', The Review of International Organizations, 5 (3), pp. 315-344.

ACA (Alliances for Climate Action). (2020) 'Alliances for Climate Action website' [online]. Available from: https://www.alliancesforclimateac tion.org/ [Accessed 4 June 2020].

Adger, W. N., Eakin, H. and Winkels, A. (2009) 'Nested and Teleconnected Vulnerabilities to Environmental Change', Frontiers in Ecology and the Environment, 7 (3), pp. 150-157.

Andonova, L. B., Hale, T. N. and Roger, C. B. (2017) 'National Policy and Transnational Governance of Climate Change: Substitutes or Complements?', International Studies Quarterly, 61 (2), pp. 253-268.

Bäckstrand, K., Kuyper, J. W., Linnér, B.-O. and Lövbrand, E. (2017) 'Nonstate Actors in Global Climate Governance: from Copenhagen to Paris and Beyond', Environmental Politics, 26 (4), pp. 561-579.

Bäckstrand, K. and Kuyper, J. W. (2017) 'The Democratic Legitimacy of Orchestration: the UNFCCC, Non-state Actors, and Transnational Climate Governance', Environmental Politics, 26 (4), pp. 764-788.

Benzie, M. and Persson, A. (2019) 'Governing Borderless Climate Risks: Moving Beyond the Territorial Framing of Adaptation', International Environmental Agreements: Politics, Law and Economics, 19 (4-5), pp. 369-393.

Bernstein, S. and Hoffmann, M. (2018) "The Politics of Decarbonization and the Catalytic Impact of Subnational Climate Experiments', Policy Sciences, 51 (2), pp. 189-211.

Biermann, F., Chan, M., Mert, A. and Pattberg, P. H. (2012) 'The Overall Effects of Partnerships for Sustainable Development: More Smoke Than Fire?', in P. H. Pattberg, F. Biermann, S. Chan and A. Mert (eds.), Public-Private Partnerships for Sustainable Development. Emergence, Influence and Legitimacy. Cheltenham: Edward Elgar, pp. 69-87.

Biermann, F., Kanie, N. and Kim, R. E. (2017) 'Global Governance by Goal-setting: the Novel Approach of the UN Sustainable Development Goals', Current Opinion in Environmental Sustainability, 26-27, pp. 26-31.

Blok, K., Höhne, N., Van Der Leun, K. and Harrison, N. (2012) 'Bridging the Greenhouse-gas Emissions Gap', Nature Climate Change, 2 (7), pp. 471-474.

Bradley, D. T., Mansouri, M. A., Kee, F. and Garcia, L. M. T. (2020) 'A Systems Approach to Preventing and Responding to COVID-19', EClinicalMedicine, 21 (2020), pp. 100325. https://doi.org/10.1016/j.ec linm.2020.100325

Chan, S. and Amling, W. (2019) 'Does Orchestration in the Global Climate Action Agenda Effectively Prioritize and Mobilize Transnational Climate Adaptation Action?', International Environmental Agreements: Politics, Law and Economics, 19 (4-5), pp. 429-446.

Chan, S., Boran, I., van Asselt, H., lacobuta, G., Niles, N., Rietig, K. et al. (2019) 'Promises and Risks of Nonstate Action in Climate and
Sustainability Governance', Wiley Interdisciplinary Reviews: Climate Change, 10 (3), pp. e572.

Chan, S., Brandi, C. and Bauer, S. (2016) 'Aligning Transnational Climate Action with International Climate Governance: The Road from Paris', Review of European, Comparative and International Environmental Law, 25 (2), pp. 238-247.

Chan, S., Ellinger, P. and Widerberg, O. (2018a) 'Exploring National and Regional Orchestration of Non-State Action for a $<1.5$ C World', International Environmental Agreements: Politics, Law and Economics, 18 (1), pp. 135-152.

Chan, S., Falkner, R., Goldberg, M. and van Asselt, H. (2018b) 'Effective and Geographically Balanced? An Output-based Assessment of Nonstate Climate Actions', Climate Policy, 18 (1), pp. 24-35.

Chan, S. and Pauw, P. (2014) 'A Global Framework for Climate Action: Orchestrating Non-state and Subnational Initiatives for More Effective Global Climate Governance (No. 34/2014). DIE Discussion Paper.

Chan, S., van Asselt, H., Hale, T., Abbott, K. W., Beisheim, M., Hoffmann, $M$. et al. (2015) 'Reinvigorating International Climate Policy: A Comprehensive Framework for Effective Nonstate Action', Global Policy, 6 (4), pp. 466-473.

ClimateSouth. (2018) 'Cooperative Climate Action: Global Performance \& Delivery in the Global South. Preliminary findings of the ClimateSouth Project for the Global Climate Action Summit' [online]. Available from: https://www.geg.ox.ac.uk/sites/geg.bsg.ox.ac.uk/files/2018-11/Climate South\%20-\%20GCAS\%20Brief.pdf [Accessed 4 June 2020].

Cohen-Shacham, E., Walters, G., Janzen, C. and Maginnis, S. (eds.) (2016) Nature-Based Solutions to Address Global Societal Challenges. Gland: IUCN.

Dinesh, D. (2019) 'A Tipping Point for Climate Action in Food Systems? Reflections from the UN Climate Action Summit and Climate Week NYC', GCIAR CCAFS News Blog, 27 September 2019 [online]. Available from: https://ccafs.cgiar.org/blog/tipping-point-climate-action-foodsystems-reflections-un-climate-action-summit-and-climate-week\#. XrkxNcBCSUk [Accessed 4 June 2020].

Doswald, N. and Osti, M. (2011) Ecosystem-based Approaches to Adaptation and Mitigation: Good Practice Examples and Lessons Learned in Europe. Bonn: Federal Agency for Nature Conservation.

Dryzek, J. S. and Pickering, J. (2018) The politics of the Anthropocene. Oxford: Oxford University Press.

Dzebo, A. (2019) 'Effective Governance of Transnational Adaptation Initiatives', International Environmental Agreements: Politics, Law and Economics, 19 (4-5), pp. 447-466.

EASAC (European Academies Science Advisory Council). (2019) The Imperative of Climate Action to Protect Human Health in Europe. Halle: EASAC [online]. Available from: https://easac.eu/publications/de tails/the-imperative-of-climate-action-to-protect-human-health-ineurope/ [Accessed 4 June 2020].

European Commission. (2020) Progress on Climate Action in Latin America: Nationally Determined Contributions as of 2019. Brussels: European Commission [online]. Available from: http://euroclimaplus. org/images/Destacados/2020/Estudio-Avances-INGLES-20-5-2020.pdf [Accessed 4 June 2020].

Galvanizing the Groundswell of Climate Actions. (2019) 'Options paper. Options for Global Climate Action in the UNFCCC after 2020 December 2019'. Galvanizing the Groundswell of Climate Actions [online]. Available from: https://static1.squarespace.com/static/552be 32ce4b0b269a4e2ef58/t/5ddda576377ff72cee46b1 be/1574806905802/ 32+GGCA.+Options+for+Global+Climate+Action+in+the+UNFCCC+after +2020.+Dec+2019.pdf [Accessed 8 June 2020]

GCF (Green Climate Fund). (2020) 'Process for Readiness Support' [online]. Available from: https://www.greenclimate.fund/readiness/ process [Accessed 4 June 2020].

Global Covenant of Mayors. (2018) 'Implementing Climate Ambition. Global Covenant of Mayors 2018 Global Aggregation Report'. Global Covenant of Mayors [online]. Available from: https://www.globalcove nantofmayors.org/wp-content/uploads/2018/09/2018_GCOM_report_ web.pdf [Accessed 4 June 2020]. 
GO FAIR Initiative. (n.d.) 'FAIR Guiding Principles for scientific data management and stewardship'. Available from: https://www.go-fair. org/fair-principles/ [Accessed 8 November 2020].

Google (n.d.) 'Google Environmental Insights Explorer'. Google [online]. Available from: https://insights.sustainability.google/ [Accessed 8 November 2020].

Hale, T. (2016) "'All Hands on Deck": The Paris Agreement and Nonstate Climate Action', Global Environmental Politics, 16 (3), pp. 12-22.

Hale, T. (2020) 'Catalytic cooperation', Global Environmental Politics, 20 (4), pp. 73-98.

Hale, T., Chan, S., Hsu, A., Clapper, A., Elliott, C., Faria, P. et al. (2020) 'Sub-and Non-state Climate Action: A Framework to Assess Progress, Implementation and Impact', Climate Policy, 1-15. https://doi.org/10. 1080/14693062.2020.1828796 [Epub ahead of print].

Hale, T. and Roger, C. (2014) 'Orchestration and Transnational Climate Governance', The Review of International Organizations, 9 (1), pp. 59 82.

Hermwille, L. (2018) 'Making Initiatives Resonate: How Can Non-state Initiatives Advance National Contributions under the UNFCCC?', International Environmental Agreements: Politics, Law and Economics, 18 (3), pp. 447-466.

Hermwille, L., Siemons, A., Förster, H. and Jeffery, L. (2019) 'Catalyzing Mitigation Ambition under the Paris Agreement: Elements for an Effective Global Stocktake', Climate Policy, 19 (8), pp. 988-1001.

Hobbhahn, N., Fears, R., Haines, A. and Ter Meulen, V. (2019) 'Urgent Action is Needed to Protect Human Health from the Increasing Effects of Climate Change', The Lancet Planetary Health, 3 (8), pp. e333-e335.

Hsu, A., Brandt, J., Widerberg, O., Chan, S. and Weinfurter, A. (2019a) 'Exploring Links between National Climate Strategies and Non-state and Subnational Climate Action in Nationally Determined Contributions (NDCs)', Climate Policy, 20 (4), pp. 443-457.

Hsu, A., Cheng, Y., Weinfurter, A., Xu, K. and Yick, C. (2016) 'Track Climate Pledges of Cities and Companies', Nature, 532 (7599), pp. 303-306.

Hsu, A., Höhne, N., Kuramochi, T., Roelfsema, M., Weinfurter, A., Xie, Y. et al. (2019b) 'A Research Roadmap for Quantifying Non-State and Subnational Climate Mitigation Action', Nature Climate Change, 9 (1), pp. 11-17.

Hsu, A., Khoo, W., Goyal, N. and Wainstein, M. (2020b) 'Next-generation Digital Ecosystem for Climate Data Mining and Knowledge Discovery: A Review of Digital Data Collection Technologies', in Special Issue: Innovations and Perspectives in Data Mining and Knowledge Discovery', Frontiers in Big Data, 3 (29), pp. 1-19.

Hsu, A., Moffat, A. S., Weinfurter, A. J. and Schwartz, J. D. (2015) 'Towards a New Climate Diplomacy', Nature Climate Change, 5 (6), pp. 501-503.

Hsu, A., Tan, J., Ng, Y. M., Toh, W., Vanda, R. and Goyal, N. (2020a) 'Performance Determinants Show European Cities Are Delivering on Climate Mitigation', Nature Climate Change, 10 (11), pp. 1015-1022.

Hsu, A., Widerberg, O., Weinfurter, A., Chan, S., Roelfsema, M. and Lütkehermöller, K. et al. (2018) 'Bridging the Emissions Gap: The Role of Non-state and Subnational Actors' in United Nations Environment Programme (UNEP) (eds.), The Emissions Gap Report 2018. A UN Environment Synthesis Report. Nairobi: UNEP, pp. 29-42.

Huang, Y. (2013) 'Policy Experimentation and the Emergence of Domestic Voluntary Carbon Trading in China', East Asia, 30 (1), pp. 67-89.

Hultman, N., Calhoun, K., Bodnar, P., Kennedy, K., Manion, M., Hansel, P. et al. (2018) 'Fulfilling America's Pledge: How States, Cities and Businesses are Leading the United States to a Low-carbon Future'. New York: Bloomberg Philanthropies [online]. Available from: https:// www.bbhub.io/dotorg/sites/28/2018/09/Fulfilling-Americas-Pledge-2018. pdf [Accessed 4 June 2020].

Hultman, N. E., Clarke, L., Frisch, C., Kennedy, K., McJeon, H., Cyrs, T. et al. (2020) 'Fusing Subnational With National Climate Action Is
Central to Decarbonization: the Case of the United States', Nature Communications, 11 (1), pp. 1-10.

Hultman, N., Frisch, C., Clarke, L., Kennedy, K., Bodnar, P., Hansel, P. et al. (2019) 'Accelerating America's Pledge: Going All-in to Build a Prosperous, Low-carbon Economy for the United States'. New York: Bloomberg Philanthropies [online]. Available from: https://www. bbhub.io/dotorg/sites/28/2019/12/Accelerating-Americas-Pledge.pdf [Accessed 4 June 2020].

ICAT (Initiative for Climate Action Transparency). (2018) 'Non-state and Subnational Action Guide: Integrating the Impact of Non-state and Subnational Mitigation Actions into National Greenhouse Gas Projects, Targets and Planning'. Berlin: New Climate Institute and World Resources Institute [online]. Available from: https://climateac tiontransparency.org/wp-content/uploads/2020/04/Non-State-and-Sub national-Action-Assessment-Guide.pdf [Accessed 4 June 2020].

Jacobs, M. (2016) 'High Pressure for Low Emissions: How Civil Society Created the Paris Climate Agreement', Juncture, 22 (4), pp. 314-323.

Jordan, A. J., Huitema, D., Hildén, M., Van Asselt, H., Rayner, T. J., Schoenefeld, J. J. and Boasson, E. L. (2015) 'Emergence of Polycentric Climate Governance and its Future Prospects', Nature Climate Change, 5 (11), pp. 977-982.

Keohane, R. O. and Victor, D. G. (2016) 'Cooperation and Discord in Global Climate Policy', Nature Climate Change, 6 (6), pp. 570-575.

Krasner, S. D. (1982) 'Structural Causes and Regime Consequences: Regimes as Intervening Variables', International Organization, 36 (2), pp. 185-205.

Kuramochi, T., Roelfsema, M., Hsu, A., Lui, S., Weinfurter, A., Chan, S. et al. (2020) 'Beyond National Climate Action: The Impact of Region, City, and Business Commitments on Global Greenhouse Gas Emissions', Climate Policy, 20 (3), pp. 275-291.

Kuyper, J. W., Linnér, B. O. and Schroeder, H. (2018) 'Non-state Actors in Hybrid Global Climate Governance: Justice, Legitimacy, and Effectiveness in a Post-Paris Era', Wiley Interdisciplinary Reviews: Climate Change, 9 (1), pp. e497.

LEDS LAC. (2020) 'Regional Platform for Resilient Development Strategies and Emissions Reduction' [online]. Available from: http:// ledslac.org/ [Accessed 4 June 2020].

Lui, S., Kuramochi, T., Smit, S., Roelfsema, M., Hsu, A., Weinfurter, A. et al. (2020) 'Correcting Course: The Emission Reduction Potential of International Cooperative Initiatives', Climate Policy, 1-19. [Epub ahead of print].

Marsal-Llacuna, M. L. (2019) 'How to Succeed in Implementing (Smart) Sustainable Urban Agendas: "Keep Cities Smart, Make Communities Intelligent"', Environment, Development and Sustainability, 21 (4), pp. 1977-1998.

Mert, A. (2019) 'Democracy in the Anthropocene: A New Scale', in E. Lövbrand and F. Biermann (eds.), Anthropocene Encounters: New Directions in Green Political Thinking. Cambridge: Cambridge University Press, pp. 107-122.

Michaelowa, K. and Michaelowa, A. (2017) 'Transnational Climate Governance Initiatives: Designed for Effective Climate Change Mitigation?', International Interactions, 43 (1), pp. 129-155.

Namande, G. (2018) 'East Africa Holds a Regional Climate Change Technical Working Group Meeting (11-13 June 2018, Nairobi, Kenya)' [online]. Available from: https://unfccc.int/sites/default/files/resource/ RCC\%20newsletter\%20article-EAC\%20CCTWG\%20meeting\%20\%2800 2\%29.pdf [Accessed 4 June 2020].

Pattberg, P., Widerberg, O. and Kok, M. T. J. (2019) 'Towards a Global Biodiversity Action Agenda', Global Policy, 10 (3), pp. 385-390.

Roelfsema, M., Harmsen, M., Olivier, J. J., Hof, A. F. and van Vuuren, D. P. (2018) 'Integrated Assessment of International Climate Mitigation Commitments outside the UNFCCC', Global Environmental Change, 48 (2018), pp. 67-75.

Roger, C., Hale, T. and Andonova, L. (2017) 'The Comparative Politics of Transnational Climate Governance', International Interactions, 43 (1), pp. 1-25. 
Scobie, M. (2019) 'Sustainable Development and Climate Change Adaptation: Goal Interlinkages and the Case SIDS', in C. Klöck and M. Fink (eds.), Dealing with Climate Change on Small Islands: Towards Effective and Sustainable Adaptation. Göttingen: Universitätsverlag Göttingen, pp. 101-122.

UNEP (2019) Emissions Gap Report 2019. Nairobi: UNEP.

UNFCCC. (2015) 'Decision 1/CP.21, Adoption of the Paris Agreement', UN Doc. FCCC/CP/2015/10/Add.1. Bonn: UNFCCC Secretariat.

UNFCCC (2017) 2017 Yearbook of Global Climate Action. Bonn: UNFCCC Secretariat.

UNFCCC (2018) 2018 Yearbook of Global Climate Action. Bonn: UNFCCC Secretariat.

UNFCCC. (2019a) 'Decision 1.CP/25, Chile Madrid Time for Action', UN Doc. FCCC/CP/2019/13/Add. 1. Bonn: UNFCCC. Secretariat.

UNFCCC (2019b) 2019 Yearbook of Global Climate Action. Bonn: UNFCCC Secretariat.

UNFCCC. (2020) Climate Action Pathways. Bonn: UNFCCC Secretariat [online]. Available from: https://unfccc.int/climate-action/marrakechpartnership/reporting-and-tracking/climate_action_pathways [Accessed 8 November 2020].

van Staden, M. and Appleby, K. (2019) 'CDP and ICLEl: Introducing Streamlined Climate Reporting', CityTalk, A Blog by ICLEI, 11 February 2019 [online]. Available from: http://talkofthecities.iclei.org/cdp-and-ic lei-introducing-streamlined-climate-reporting/ [Accessed 04 June 2020].

Watts, N., Amann, M., Arnell, N., Ayeb-Karlsson, S., Belesova, K., Boykoff, M. et al. (2019) 'The 2019 Report of The Lancet Countdown on Health and Climate Change: Ensuring that the Health of a Child Born Today is not Defined by a Changing Climate', The Lancet, 394 (10211), pp. 1836-1878.

Widerberg, O. (2017) 'The "Black Box" Problem of Orchestration: How to Evaluate the Performance of the Lima-Paris Action Agenda', Environmental Politics, 26 (4), pp. 715-737.

Widerberg, O. and Stripple, J. (2016) 'The Expanding Field of Cooperative Initiatives for Decarbonization: A Review of Five Databases', Wiley Interdisciplinary Reviews: Climate Change, 7 (4), pp. 486-500.

\section{Author Information}

Sander Chan is a Senior Researcher at the Global Center on Adaptation and Associated Researcher at the German Development Institute/ Deutsches Institut für Entwicklungspolitik (DIE), he is also Adjunct Assistant Professor at the Copernicus Institute of Sustainable Development at Utrecht University. His research interests include sustainable development and climate change governance, and international relations.

Idil Boran is an Associate Professor at the Department of Philosophy and Faculty Member at the Dahdaleh Institute for Global Health Research, York University and Associate Researcher at the German Development Institute/Deutsches Institut für Entwicklungspolitik (DIE). Her research interest covers social and political theory, philosophy and public policy, environmental governance and modern political thought.

Harro van Asselt is a Professor of Climate Law and Policy with the University of Eastern Finland Law School, a Visiting Researcher with the Copernicus Institute of Sustainable Development at Utrecht University, and an Associate with the Stockholm Environment Institute. He focuses on international climate change governance.

Paula Ellinger is Program Coordinator for Amazon and Climate Change Strategies at Fundación Avina. She focuses on arresting deforestation, environmental sustainability and livelihoods.

Miriam Garcia is a Ph.D. Candidate at the Institute of International Relations - University of São Paulo. She holds a Master's Degree in International Relations from the Institut d'Études Politiques de Paris.
Thomas Hale is Associate Professor in Global Public Policy, Blavatnik School of Government and fellow of St Antony's College. He focuses on global environmental and economic issues linked to globalisation and interdependence.

Lukas Hermwille is Project Coordinator at the Wuppertal Institute for Climate, Environment and Energy and PhD candidate at the Institute for Environmental Studies (IVM) at Vrije Universiteit Amsterdam. His work focuses on global climate and energy governance.

Kennedy Liti Mbeva is a PhD Candidate in the School of Social and Political Science, and Climate \& Energy College, at the University of Melbourne; and the Deputy-Convenor of the African Research \& Impact Network (ARIN). He is interested in international economic and environmental governance.

Ayşem Mert is Associate Senior Lecturer at the Department of Political Science, Stockholm University. Her work focuses on sustainability governance, public-private cooperation, and discourses of democracy in the Anthropocene.

Charles B. Roger is an Assistant Professor at the Institute Barcelona d'Estudis Internacionals (IBEI). His research interests are International Organization, International Law, International Political Economy, Global Environmental Politics.

Amy Weinfurter is Senior Water Resources Specialist at WaterNow Alliance.

Oscar Widerberg is an Assistant Professor at the Institute for Environmental Studies (IVM), Vrije Universiteit Amsterdam and fellow at the Earth System Governance project. He conducts research on policy and governance for sustainability, primarily at the international and transnational level.

Paulette Bynoe is a Senior Lecturer and the former Dean of the Faculty of Earth and Environmental Sciences at the University of Guyana. She is interested in Environmental education and awareness and training, climate change vulnerability and adaptation, environmental resources policies and sustainable livelihoods.

Victoria Chengo is a Research Fellow in the Climate Resilient Economies Programme at the African Centre for Technology Studies; and the Tomorrow's Cities' Nairobi Risk Hub Project Manager. She has a keen interest in climate action and governance, sustainable cities \& development - disaster risk reduction, natural resources management - energy $\&$ water development.

Ayman Cherkaoui is an International Jurist in Climate Change Law, Coordinator and Strategic Development Officer at the Mohammed VI Foundation for Environmental Protection, and Lead Counsel for Climate Change at the Center for International Sustainable Development Law

Todd Edwards is Principal Advisor and coordinator of research and analytics to the Mission 2020 campaign and Camda Lead at COP26 Climate Champions team. He holds a Ph.D. in political science and is interested in global climate governance.

Malin Gütschow holds a Master's degree in Sustainable Development from the University of Leipzig and the University of Utrecht.

Angel Hsu is Assistant Professor of Public Policy and the Environment, Ecology and Energy Program (E3P) and Founder and Director of the Data-Driven EnviroLab, an interdisciplinary research group that innovates and applies quantitative approaches to pressing environmental issues.

Nathan Hultman is Director of the Center for Global Sustainability and Associate Professor at the University of Maryland School of Public Policy. He is also Associate Director of the Joint Global Change Research Institute, and a Non-Resident Senior Fellow at the Brookings Institution. 
David Levaï is an Associate Researcher at IDDRI and a Fellow at the United Nations Foundation (UNF) where he focuses on international governance and cooperation for climate action as well as climate finance.

Saffran Mihnar is co-founder at Baslutions and Director for Development and Communication at EarthLanka. He is an advocate for climate solutions focused on communication, campaigning, and negotiations.

Sara Posa is a Research Analyst at World Benchmarking Alliance where she focuses on sustainable food supply chains. She holds a Master's degree in Sustainable development from the University of Utrecht.

Mark Roelfsema is a Researcher at Copernicus Institute of Sustainable Development, Utrecht University. He is a Policy Researcher in the field of international climate change and is interested in sustainability with a focus on environmental and financial issues.
Bryce Rudyk is Adjunct Professor of Law and Director, United Nations Diplomacy Clinic at the New York University School of Law, Director and Senior Fellow, International Environmental law at the Guarini Center on Environmental, Energy and Land Use Law, and Legal Advisor, Alliance of Small Island States (AOSIS).

Michelle Scobie is a Lecturer at the Institute of International Relations, The University of the West Indies, St. Augustine, Trinidad and Tobago. Co-editor of the Caribbean Journal of International Relations and Diplomacy, her research focuses on global environmental governance and small island developing states.

Manish Kumar Shrivastava is Assistant Professor at the Department of Energy and Environment, TERI School of Advanced Studies, New Delhi. $\mathrm{He}$ is interested in Sustainable development and climate change from the perspective of justice and governance. 


\section{University Library}

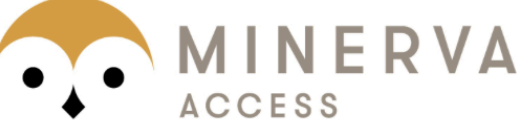

A gateway to Melbourne's research publications

Minerva Access is the Institutional Repository of The University of Melbourne

\section{Author/s:}

Chan, S;Boran, I;van Asselt, H;Ellinger, P;Garcia, M;Hale, T;Hermwille, L;Liti Mbeva, K;Mert, A;Roger, CB;Weinfurter, A;Widerberg, O;Bynoe, P;Chengo, V;Cherkaoui, A;Edwards, T;Gutschow, M;Hsu, A;Hultman, N;Levai, D;Mihnar, S;Posa, S;Roelfsema, M;Rudyk, B;Scobie, M;Shrivastava, MK

Title:

Climate Ambition and Sustainable Development for a New Decade: A Catalytic Framework

Date:

2021-04-06

\section{Citation:}

Chan, S., Boran, I., van Asselt, H., Ellinger, P., Garcia, M., Hale, T., Hermwille, L., Liti Mbeva, K., Mert, A., Roger, C. B., Weinfurter, A., Widerberg, O., Bynoe, P., Chengo, V., Cherkaoui, A., Edwards, T., Gutschow, M., Hsu, A., Hultman, N. ,... Shrivastava, M. K. (2021). Climate Ambition and Sustainable Development for a New Decade: A Catalytic Framework. GLOBAL POLICY, 12 (3), pp.245-259. https://doi.org/10.1111/1758-5899.12932.

Persistent Link:

http://hdl.handle.net/11343/288712

License:

CC-BY-NC 